\title{
Agronomic Biofortification of Maize with Zinc and Iron Micronutrients
}

\author{
Nikhil Kumar and Salakinkop SR* \\ University of Agricultural Sciences, India \\ *Corresponding author: Salakinkop SR, Associate Professor, AICRP on Maize, Main Agricultural Research Station, University of Agricultural Sciences, \\ India
}

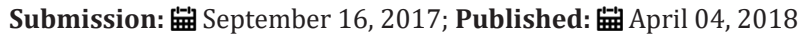

\begin{abstract}
A field experiment on agronomic biofortification with zinc and iron micronutrients in maize was carried out during kharif season of 2015 at Agricultural Research Station, Bailhongal. The experiment was laid out in randomized block design with factorial concept with three replications consisted of 16 treatment combinations involving seed treatment (no seed treatment and seed treatment with Zn and Fe each@1\%), soil application

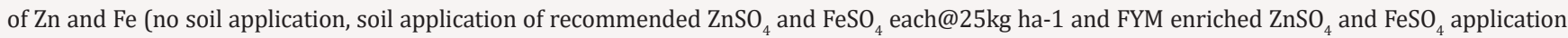
each@15 kg ha ${ }^{-1}$ and $\mathrm{FYM}$ enriched $\mathrm{ZnSO}_{4}$ and $\mathrm{FeSO}_{4}$ application each@25kg ha-1) and foliar application of Zn and Fe at 45 DAS (no foliar and foliar spray of $\mathrm{ZnSO}_{4}$ and $\mathrm{FeSO}_{4}$ each@0.5\%).

Soil application of FYM enriched $\mathrm{ZnSO}_{4}$ and $\mathrm{FeSO}_{4}$ each@25 and $15 \mathrm{~kg}$ ha-1 recorded higher yield and yield attributes. Similarly foliar spray of ZnSO and $\mathrm{FeSO}_{4}$ each@0.5\% at 45 DAS found superior over no foliar spray. Among the interactions treatment combination involving seed treatment, soil application of FYM enriched $\mathrm{ZnSO} 4$ and $\mathrm{FeSO}_{4}$ each@15 kg ha ${ }^{-1}$ and foliar spray recorded the higher grain yield (78.5q ha-1), Stover yield (106.4q ha-1) and yield parameters viz., cob length $(20.7 \mathrm{~cm})$, cob weight $(286.7 \mathrm{~g})$, grain weight per cob $(190.0 \mathrm{~g})$, number of grains per cob (684.8) and test weight $(31.4 \mathrm{~g})$ also higher values in growth parameters viz., plant height, leaf area index, SPAD values and dry matter production compared to no seed, soil and

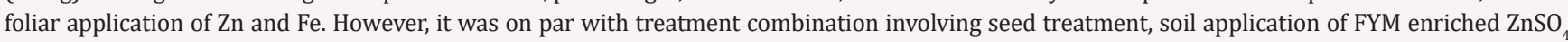
and $\mathrm{FeSO}_{4}$ each@25 kg ha-1 and foliar spray.
\end{abstract}

Keywords: Biofortification; FYM enrichment; Micronutrients; Growth; Yield

\section{Introduction}

Maize (Zea mays L.) is the third most important cereal crop next to wheat and rice in the world as well as in India. It is cultivated in both tropical and temperate regions of the world. Maize is called as "queen of cereals" and "miracle crop" because of its higher productive potential compared to any other cereal crop. Maize is the most important cereal feed for livestock and critical staple food for people living in Asia, Africa and Latin America. In India, out of total production of maize, 45 per cent is consumed as a staple food in various forms [1]. Maize grains utilized in many ways like making roti, rawa, maida, popcorn and some industrial products like protein foods, glucose powder, starch etc. Beside this, stover serves as a good fodder for cattle. Hence, it is proudly known as "queen of cereals and king of fodder crops". Maize is cultivated in all season's viz. kharif, rabi and summer. In India maize is cultivated on $9.4 \mathrm{~m}$ ha with production of $2.3 \mathrm{~m}$ tonnes and productivity of 2.55 tonnes $\mathrm{ha}^{-1}$. In Karnataka it is being grown on an area of $1.36 \mathrm{~m}$ ha with production of $4.4 \mathrm{~m}$ tonnes and the productivity of $3.5 \mathrm{t} \mathrm{ha}^{-1}$ [2]. On an average maize grain is composed of 60 per cent carbohydrate, 10 per cent protein, 4.5 per cent oil, 3.5 percent fibre and 2 per cent minerals. It also contains $348 \mathrm{mg} \mathrm{P}, 286 \mathrm{mg} \mathrm{K}, 114 \mathrm{mg} \mathrm{S}, 10 \mathrm{mg} \mathrm{Ca}$, $2.3 \mathrm{mg}$ Fe and 90 microgram of carotene per $100 \mathrm{~g}$ grain.

All India Coordinated Research Project on Micronutrients delineated the soils of India regarding the deficiency of micronutrients. At present about 48.1 percent of Indian soils are deficient in diethylene-tri amine pent acetate (DTPA) extractable zinc and 11.2 percent in iron. Zinc (Zn) and iron (Fe) deficiencies are well-documented public health issue and an important soil fertility constraint to crop production. Generally, there is a close geographical overlap between soil deficiency and human deficiency of $\mathrm{Zn}$ and Fe indicating a high requirement for increasing concentrations of micronutrients in food crops. Higher rice yield was recorded with combined soil application of $\mathrm{ZnSO}_{4}$ and $\mathrm{FeSO}_{4}$ each@25kg ha-1 and foliar spray of $\mathrm{ZnSO}_{4}$ and FeSO4 each@0.5\% [3]. A rapid and complementary approach is therefore required for biofortification of food crops with $\mathrm{Zn}$ and Fe in the short term.

\section{Material and Method}

The field experiment was conducted at Agricultural Research Station (ARS), Bailhongal, during kharif season of 2015 which is 
situated in Northern Transitional Zone of Karnataka and located between $15^{\circ} .81^{\prime}$ North latitude and $74^{\circ} .86^{\prime}$ East longitudes with an altitude of $546 \mathrm{~m}$ above mean sea level. The soil of the experimental site is medium black in nature and the texture of the soil is clayey, belonging to the order vertisols. Composite soil sample were drawn from 0 to $15 \mathrm{~cm}$ depth from the experimental site before sowing and was analyzed for physical and chemical properties. Clayey in texture $(10.65 \%$ sand, $30.0 \%$ silt, $59.12 \%$ clay), pH 7.3, E.C 0.34 , low in organic carbon $\left(4.8 \mathrm{~g} \mathrm{~kg}^{-1}\right)$, available nitrogen $(218.4 \mathrm{~kg}$ ha ${ }^{1}$ ), available phosphorus (36.4kg ha-1) available potassium $(347.2 \mathrm{~kg}$ ha $\left.^{-1}\right)$ available zinc $(0.76 \mathrm{ppm})$ and available iron (4.19ppm).

The experiment was laid out in Randomized Complete Block Design (factorial concept) with 16 treatment combinations. Treatment combinations involving seed treatmenti.eno seed treatment $\left(\mathrm{T}_{1}\right)$ and seed treatment with $\mathrm{Zn}$ and $\mathrm{Fe}$ each@1\% $\left(\mathrm{T}_{2}\right)$, soil application of $\mathrm{Zn}$ and Fe i.e. no soil application (S1), soil application of recommended $\mathrm{ZnSO}_{4}$ and $\mathrm{FeSO}_{4}$ each@25kg ha-1 (S2), FYM enriched $\mathrm{ZnSO}_{4}$ and $\mathrm{FeSO}_{4}$ application each@15kg ha-1 (S3) and FYM enriched $\mathrm{ZnSO}_{4}$ and $\mathrm{FeSO}_{4}$ application each@25 $\mathrm{kg} \mathrm{ha}^{-1}\left(\mathrm{~S}_{4}\right)$ and foliar application of $\mathrm{Zn}$ and Fe i.e. no foliar $\left(\mathrm{F}_{1}\right)$ and foliar spray of $\mathrm{ZnSO}_{4}$ and FeSO4 each@0.5 \% (F2) at 45 DAS.

\section{Results and Discussion}

Crop performance in terms of growth (plant height, leaf area, dry matter production) and yield attributes was significantly increased due application of $\mathrm{Zn}$ and Fe. The beneficial effect of application of Zn and Fe enriched FYM was clearly noticed over no application (control). Soil application of FYM enriched $\mathrm{ZnSO}_{4}$ and $\mathrm{FeSO}_{4}$ each@25kg ha-1 (76.2q ha-1), FYM enriched $\mathrm{ZnSO}_{4}$ and $\mathrm{FeSO}_{4}$ each@15kg ha-1 (75.0q ha ${ }^{-1}$ ) and application of recommended ZnSO4 and FeSO4 each@25kg ha-1 (69.4q ha $\left.{ }^{-1}\right)$ increased the grain yield by 19.8, 18.5 and 11.9 per cent respectively over no application of $\mathrm{Zn}$ and Fe (61.1q ha-1) (Table 1).

Table 1: Grain yield, stover yield and harvest index of maize as influenced by seed, soil and foliar application of zinc and iron. Means followed by same letters in the column do not differ significantly by DMRT $(p=0.05)$.

\begin{tabular}{|c|c|c|c|}
\hline & Grain Yield (q ha-1) & $\begin{array}{c}\text { Stover Yield (q } \\
\text { ha }^{-1} \text { ) }\end{array}$ & $\begin{array}{c}\text { Harvest index } \\
\text { (\%) }\end{array}$ \\
\hline \multicolumn{4}{|c|}{ Factor I : Seed treatment } \\
\hline $\mathrm{T}_{1}$ : No seed treatment with $\mathrm{Zn}$ and Fe & $69.70^{\mathrm{a}}$ & $100.89^{\mathrm{a}}$ & $40.46^{\mathrm{a}}$ \\
\hline $\mathrm{T}_{2}:$ Seed treatment with $\mathrm{Zn}$ and $\mathrm{Fe}$ & $71.17^{\mathrm{a}}$ & $102.41^{\mathrm{a}}$ & $40.87^{\mathrm{a}}$ \\
\hline S. Em \pm & 1.55 & 0.68 & 0.64 \\
\hline \multicolumn{4}{|c|}{ Factor II : Soil application } \\
\hline $\mathrm{S}_{1}$ : Control (No application of $\mathrm{Zn}$ and Fe ) & $61.11^{\mathrm{b}}$ & $95.49^{\mathrm{b}}$ & $38.95^{\mathrm{a}}$ \\
\hline $\mathrm{S}_{2}:$ Soil application of recommended $\mathrm{ZnSO}_{4}$ and $\mathrm{FeSO}_{4}$ each@25 $\mathrm{kg} \mathrm{ha}^{-1}$ & $69.42 \mathrm{a}^{\mathrm{b}}$ & $99.26 \mathrm{a}^{\mathrm{b}}$ & $41.05^{\mathrm{a}}$ \\
\hline $\mathrm{S}_{3}:$ FYM enriched $\mathrm{ZnSO}_{4}$ and $\mathrm{FeSO}_{4}$ application each@15kg ha ${ }^{-1}$ & $75.02 \mathrm{a}^{\mathrm{b}}$ & $105.87^{\mathrm{a}}$ & $41.10^{\mathrm{a}}$ \\
\hline $\mathrm{S}_{4}:$ FYM enriched $\mathrm{ZnSO}_{4}$ and $\mathrm{FeSO}_{4}$ application each@25kg ha-1 & $76.18^{\mathrm{a}}$ & $105.97^{\mathrm{a}}$ & $41.55^{\mathrm{a}}$ \\
\hline S. $\mathrm{Em} \pm$ & 2.19 & 0.97 & 0.91 \\
\hline \multicolumn{4}{|c|}{ Factor III: Foliar spray } \\
\hline $\mathrm{F}_{1}$ : No foliar application of $\mathrm{Zn}$ and $\mathrm{Fe}$ & $68.03 \mathrm{~b}$ & $100.40 \mathrm{~b}$ & $40.28^{\mathrm{a}}$ \\
\hline $\mathrm{F}_{2}:$ Foliar application of $\mathrm{ZnSO}_{4}$ and $\mathrm{FeSO}_{4}$ each@0.5\% & $72.83^{\mathrm{a}}$ & $102.90^{\mathrm{a}}$ & $41.05^{\mathrm{a}}$ \\
\hline S. Em \pm & 1.55 & 0.68 & 0.64 \\
\hline
\end{tabular}

Similarly stover yield was increased with increased level of application of $\mathrm{Zn}$ and Fe. Soil application of FYM enriched $\mathrm{ZnSO}_{4}$ and $\mathrm{FeSO}_{4}$ each@25kg ha ${ }^{-1}\left(106 \mathrm{q} \mathrm{ha}^{-1}\right.$ ), FYM enriched $\mathrm{ZnSO}_{4}$ and FeSO4 each@15kg ha-1 (105.9q ha-1) and application of recommended $\mathrm{ZnSO}_{4}$ and FeSO4 each@25kg ha-1 (99.3q ha ${ }^{-1}$ ) increased the stover yield by $9.9,9.8$ and 3 per cent respectively over no application of $\mathrm{Zn}$ and $\mathrm{Fe}\left(95.5 \mathrm{q} \mathrm{ha} \mathrm{h}^{-1}\right)$. There was significantly higher rice yield and yield attributing characters with combined soil application of $\mathrm{ZnSO}_{4}$ and FeSO4 each@25kg ha-1 and foliar spray of $\mathrm{ZnSO}_{4}$ and $\mathrm{FeSO}_{4}$ each@0.5\% [3]. The variation in the yield was due to the variation in the yield components viz., cob length, cob weight, grain weight per cob, number of grains per cob and test weight.

The increase in grain yield of maize due to the soil application of FYM enriched $\mathrm{ZnSO}_{4}$ and $\mathrm{FeSO}_{4}$ each@ $25 \mathrm{~kg} \mathrm{ha}^{-1}$ was mainly due to the increased cob length $(19.8 \mathrm{~cm})$, cob weight $(271.35 \mathrm{~g})$, grain weight per cob (189.25g), number of grains per cob (673.5) and test weight (31.61g) compared to control (Table 2). Variation in yield and yield attributes could be traced back to the improved growth parameters like plant height, leaf area index, SPAD reading and dry matter production. Similar observations were recorded by [4] in wheat. Increase in yield was due to improved availability of micronutrients ( $\mathrm{Zn}$ and $\mathrm{Fe}$ ) which could be attributed to the formation of stable organometalic complexes of micronutrients with organic matter, especially during the enrichment process to last for a longer time and release the nutrients slowly in the soil system in such a way that the nutrients are protected from fixation and made available to the plant root system throughout the crop growth. [5]. 
Table 2: Cob weight, grains per cob, cob length, grain weight per cob and test weight of maize as influenced by seed, soil and foliar application of zinc and Iron.

\begin{tabular}{|c|c|c|c|c|c|}
\hline & $\begin{array}{c}\text { Cob Weight } \\
\text { (g) }\end{array}$ & $\begin{array}{l}\text { Grains Per } \\
\quad \text { Cob }\end{array}$ & $\begin{array}{c}\text { Cob } \\
\text { Length } \\
\text { (cm) }\end{array}$ & $\begin{array}{c}\text { Grain Weight Per Cob } \\
\text { (g) }\end{array}$ & $\begin{array}{c}\text { Test Weight } \\
\text { (g) }\end{array}$ \\
\hline \multicolumn{6}{|l|}{ Factor I : Seed treatment } \\
\hline $\mathrm{T}_{1}$ : No seed treatment with $\mathrm{Zn}$ and Fe & $254.30^{\mathrm{a}}$ & $657.43^{\mathrm{a}}$ & $18.89^{\mathrm{a}}$ & $184.44^{\mathrm{a}}$ & $30.37^{\mathrm{a}}$ \\
\hline $\mathrm{T}_{2}:$ Seed treatment with $\mathrm{Zn}$ and $\mathrm{Fe}$ & $263.93^{\mathrm{a}}$ & $662.13^{a}$ & $19.40^{\mathrm{a}}$ & $184.90^{\mathrm{a}}$ & $30.74^{\mathrm{a}}$ \\
\hline S. Em \pm & 3.50 & 4.01 & 0.21 & 0.21 & 0.14 \\
\hline \multicolumn{6}{|c|}{ Factor II : Soil application } \\
\hline $\mathrm{S}_{1}$ : Control (No application of $\mathrm{Zn}$ and $\mathrm{Fe}$ ) & $235.01^{\mathrm{b}}$ & $620.92^{\mathrm{b}}$ & $17.75^{\mathrm{b}}$ & $179.25 \mathrm{c}$ & $29.26^{b}$ \\
\hline $\begin{array}{c}\mathrm{S}_{2}: \text { Soil application of recommended } \mathrm{ZnSO}_{4} \text { and } \mathrm{FeSO}_{4} \\
\text { each@ } 25 \mathrm{~kg} \mathrm{ha}^{-1}\end{array}$ & $257.04 a^{b}$ & $659.95 a^{b}$ & $19.27^{\mathrm{a}}$ & $183.00^{\mathrm{b}}$ & $30.27^{\mathrm{ab}}$ \\
\hline $\mathrm{S}_{3}:$ FYM enriched $\mathrm{ZnSO}_{4}$ and $\mathrm{FeSO}_{4}$ application each@15kg ha ${ }^{-1}$ & $273.06^{\mathrm{a}}$ & $678.90^{\mathrm{a}}$ & $19.77^{\mathrm{a}}$ & $187.18^{\mathrm{a}}$ & $31.08^{\mathrm{a}}$ \\
\hline $\mathrm{S}_{4}:$ FYM enriched $\mathrm{ZnSO}_{4}$ and $\mathrm{FeSO}_{4}$ application each@25kg ha-1 & $271.35^{\mathrm{a}}$ & $679.35^{\mathrm{a}}$ & $19.80^{\mathrm{a}}$ & $189.25^{\mathrm{a}}$ & $31.61^{\mathrm{a}}$ \\
\hline S. Em \pm & 4.95 & 5.67 & 0.30 & 0.30 & 0.20 \\
\hline \multicolumn{6}{|c|}{ Factor III: Foliar spray } \\
\hline $\mathrm{F}_{1}$ : No foliar application of $\mathrm{Zn}$ and $\mathrm{Fe}$ & $253.87^{\mathrm{b}}$ & $653.43^{\mathrm{b}}$ & $18.78^{\mathrm{b}}$ & $183.52^{\mathrm{b}}$ & $30.30^{\mathrm{b}}$ \\
\hline $\mathrm{F}_{2}$ : Foliar application of $\mathrm{ZnSO}_{4}$ and $\mathrm{FeSO}_{4}$ each@0.5 \% & $264.35^{\mathrm{a}}$ & $666.13^{\mathrm{a}}$ & $19.51^{\text {a }}$ & $185.83^{\mathrm{a}}$ & $30.81^{\mathrm{a}}$ \\
\hline S. Em \pm & 3.50 & 4.01 & 0.21 & 0.21 & 0.14 \\
\hline
\end{tabular}

Means followed by same letters in the column do not differ significantly by DMRT ( $p=0.05)$.

The increase in the yield attributes could be due to continuous supply of organically chelated micronutrients ( $\mathrm{Zn}$ and $\mathrm{Fe}$ ) to the crop. Zn and Fe are part of the photosynthesis, assimilation and translocation of photosynthates from source (leaves) to sink (cobs) [6]. Increased grain and stover yield (72.8 and 102.9q ha-1 respectively) was also recorded with foliar spray of ZnSO4 and $\mathrm{FeSO}_{4}$ each@0.5 per cent at 45 DAS over no foliar spray (68.03

Table 3: Plant height $(\mathrm{cm})$, leaf area index, SPAD value and dry matter accumulation (g plant-1) at milking stage of maize as influenced by seed, soil and foliar application of zinc and Iron.

\begin{tabular}{|c|c|c|c|c|}
\hline & Plant Height (Cm) & $\begin{array}{l}\text { Leaf Area } \\
\text { Index }\end{array}$ & $\begin{array}{l}\text { SPAD } \\
\text { Values }\end{array}$ & $\begin{array}{c}\text { Dry Matter Accumulation } \\
\text { (G Plant }{ }^{-1} \text { ) }\end{array}$ \\
\hline \multicolumn{5}{|c|}{ Factor I : Seed treatment } \\
\hline $\mathrm{T}_{1}$ : No seed treatment with $\mathrm{Zn}$ and Fe & $187.70^{\mathrm{a}}$ & $5.82^{\mathrm{a}}$ & $50.66^{\mathrm{a}}$ & $239.32^{\mathrm{a}}$ \\
\hline $\mathrm{T}_{2}$ :Seed treatment with $\mathrm{Zn}$ and Fe & $188.73^{\mathrm{a}}$ & $5.86^{\mathrm{a}}$ & $51.22^{\mathrm{a}}$ & $241.05^{\mathrm{a}}$ \\
\hline S. Em \pm & 0.93 & 0.06 & 0.52 & 0.74 \\
\hline \multicolumn{5}{|c|}{ Factor II : Soil application } \\
\hline $\mathrm{S}_{1}$ : Control (No application of $\mathrm{Zn}$ and Fe ) & $182.26^{\mathrm{b}}$ & $5.45^{\mathrm{c}}$ & $44.96^{\mathrm{b}}$ & $215.28^{\mathrm{c}}$ \\
\hline $\begin{array}{c}\mathrm{S}_{2}: \text { Soil application of recommended } \mathrm{ZnSO}_{4} \text { and } \mathrm{FeSO}_{4} \\
\text { each@25 } \mathrm{kg} \mathrm{ha}^{-1}\end{array}$ & $186.20^{\mathrm{ab}}$ & $5.78^{\mathrm{b}}$ & $52.60^{\mathrm{a}}$ & $242.21^{\mathrm{b}}$ \\
\hline $\mathrm{S}_{3}:$ FYM enriched $\mathrm{ZnSO}_{4}$ and $\mathrm{FeSO}_{4}$ application each@15kg ha-1 & $191.58^{\mathrm{a}}$ & $6.03 \mathrm{ab}$ & $53.14^{\mathrm{a}}$ & $249.38 a^{b}$ \\
\hline $\mathrm{S}_{4}:$ FYM enriched $\mathrm{ZnSO}_{4}$ and $\mathrm{FeSO}_{4}$ application each@25kg ha-1 & $192.84^{\mathrm{a}}$ & $6.12^{\mathrm{a}}$ & $53.05^{\mathrm{a}}$ & $253.88^{\mathrm{a}}$ \\
\hline S. Em \pm & 1.31 & 0.09 & 0.74 & 1.05 \\
\hline \multicolumn{5}{|c|}{ Factor III: Foliar spray } \\
\hline $\mathrm{F}_{1}$ : No foliar application of $\mathrm{Zn}$ and $\mathrm{Fe}$ & $187.24^{\mathrm{a}}$ & $5.79^{\mathrm{b}}$ & $49.88^{\mathrm{b}}$ & $235.02^{\mathrm{b}}$ \\
\hline $\mathrm{F}_{2:}$ Foliar application of $\mathrm{ZnSO}_{4}$ and $\mathrm{FeSO}_{4}$ each@0.5 \% & $189.20^{\mathrm{a}}$ & $5.89^{\mathrm{a}}$ & $51.99^{a}$ & $245.35^{\mathrm{a}}$ \\
\hline S.Em \pm & 0.93 & 0.06 & 0.52 & 0.74 \\
\hline
\end{tabular}

Means followed by same letters in the column do not differ significantly by DMRT $(p=0.05)$. and $100.4 \mathrm{q}$ ha-1 respectively). This could be due to the improved in growth and yield attributes. Foliar spray recorded significantly improved yield components viz., cob length $(19.42 \mathrm{~cm})$, cob weight (264.3g), grains per cob (666.1), test weight (30.8g) and grain weight per cob (185.8g) over no foliar spray. Similar results were obtained by [7] (Table 3). 
Foliar application of $\mathrm{ZnSO}_{4}$ and $\mathrm{FeSO}_{4}$ each@0.5 percent at 45 DAS recorded significant improvement in growth parameters at milking stage viz., plant height $(189.2 \mathrm{~cm})$, leaf area index (5.89), SPAD values (51.6) and dry matter production(245.4g plant ${ }^{-1}$ ). Similar results were noticed by [8]. Foliar spray helped to rapid absorption of $\mathrm{Zn}$ and Fe nutrients through leaf and this resulted increase in cell division and elongation, chlorophyll content and photosynthesis. Foliar application of micronutrients might enhance dry matter transformation from store part to sink parts [9].

Interaction effect due to the seed, soil and foliar application of $\mathrm{Zn}$ and Fe revealed a significant influence on the yield of maize. There was increase in grain yield from $59.7 \mathrm{q} \mathrm{ha}^{-1}$ in control to $79.0 \mathrm{q} \mathrm{ha}^{-1}$ in combined application of $\mathrm{Zn}$ and Fe through seed; soil application of FYM enriched $\mathrm{ZnSO}_{4}$ and $\mathrm{FeSO}_{4}$ each @25kg ha-1 and foliar application $\left(\mathrm{T}_{2} \mathrm{~S}_{4} \mathrm{~F}_{2}\right)$ which accounts to increased yield by 24.4 percent over no seed, soil and foliar application (T1S1F1). Similarly stover yield increased from 94.4 in control to $106.6 \mathrm{q} \mathrm{ha}{ }^{-1}$ combined application of $\mathrm{Zn}$ and Fe through seed, soil application of FYM enriched $\mathrm{ZnSO}_{4}$ and $\mathrm{FeSO}_{4}$ each@25kg ha-1 and foliar application $\left(\mathrm{T}_{2} \mathrm{~S}_{4} \mathrm{~F}_{2}\right)$ increased the stover yield by 11.4 percent over no seed, soil and foliar application $\left(\mathrm{T}_{1} \mathrm{~S}_{1} \mathrm{~F}_{1}\right)$

Combined application of FYM enriched Zn and Fe each@25kg ha $^{-1}$ was found on par with their each@15kg ha-1. It was due to better growth parameters and yield attributes which could be comparable with best treatment combination $\left(\mathrm{T}_{2} \mathrm{~S}_{4} \mathrm{~F}_{2}\right)$. The higher grain yield with $\mathrm{Zn}$ and Fe application could be attributed to increased total dry matter production as results of better uptake of $\mathrm{Zn}$ and $\mathrm{Fe}$ and their translocation to reproductive parts. Improvement in yield attributing characters like cob length, cob weight, grains per cob, test weight and grain weight per cob was the main cause for increased maize yield in combined application of $\mathrm{Zn}$ and Fe through seed, soil and foliage.

In present investigation, important yield attributes viz., cob length $(20.4 \mathrm{~cm})$, cob weight $(275.4 \mathrm{~g})$, grain weight per cob (189.5g), number of grains per cob (683.5) and test weight (32.1g) were significantly higher under treatment combination involving application of $\mathrm{Zn}$ and Fe through seed, soil application of FYM enriched $\mathrm{ZnSO} 4$ and $\mathrm{FeSO}_{4}$ each@25kg ha-1 and foliar application $\left(\mathrm{T}_{2} \mathrm{~S}_{4} \mathrm{~F}_{2}\right)$ compared to no seed soil and foliar application $\left(\mathrm{T}_{1} \mathrm{~S}_{1} \mathrm{~F}_{1}\right)$. Difference in yield and yield attributes of maize depends upon the variation in growth parameters like plant height, leaf area index, SPAD reading and dry matter production.

However, it was on par with combined application of FYM enriched Zn and Feeach@15kg ha-1 with respect to growth parameters. Improvement in plant growth was due to soil and foliar application of $\mathrm{Zn}$ and $\mathrm{Fe}$ was due to proper nourishment of crop with nutrient supply. The increase in yield due to zinc and iron application may be attributed to their role in various physiological processes and improvement in growth components better partitioning of carbohydrates from leaf to reproductive parts resulting in increased yield. It could also be ascribed to its improvement in metallo enzymes system regulatory function and growth promoting auxin production [10].

\section{References}

1. Prasanna BM, Vasal SK, Kassahun B, Singh NN (2001) Quality protein maize. Curr Sci 81: 48-53.

2. Anonymous (2014) Agricultural Statistics at glance, Directorate of economics and statistics. Department of Agriculture and Co-operation, Ministry of Agriculture, Govt. of India.

3. Suresh S, Salakinkop SR (2016) Growth and yield of rice as influenced by biofortification of zinc and iron. J Farm Sci 29(4): 443-448.

4. Bandiwaddar TT, Patil BN (2015) Response of bread wheat (Triticumaestivum L.) to varied levels of iron and zinc enriched with organics in maize-wheat cropping sequence. Karnataka J Agric Sci 28(4): 467-473.

5. Meena MC, Patel KP, Rathod DD (2000) Effect of Zn and Fe enriched FYM on mustard yield and micronutrients availability in loamy sand soil of Anand. J Indian Soc Soil Sci 54: 495-499.

6. Singh JP, Dahiya DJ, Vinod K (1995) Effect of nitrogen and iron supply on growth and nutrient uptake of maize on sandy soil. Crop Res 10(3): 271-276.

7. Hythum MS, Nasser KB (2012) Importance of Micronutrients and its Application Methods for Improving Maize (Zea mays L.) Yield Grown in Clayey Soil. American Eurasian J Agric Environ Sci 12(7): 954-959.

8. Potarzycki J, Grzebisz W (2009) Effect of zinc foliar application on grain yield of maize and its yielding components. Plant Soil Environ 55(12): 519-527.

9. Singaraval R, Parasath V, Elayaraja D (1996) Effect of organics and micronutrients on the growth, yield of groundnut in coastal soil. Int J Agric Sci 2(2): 401-402.

10. Veeranagappa P, Prakash HC, Basavaraj MK, Saqeebulla H (2010) Effect of zinc enriched compost on yield and nutrient uptake of rice (Oryzasativa L.). J Biol Sci 3(1): 23-29.

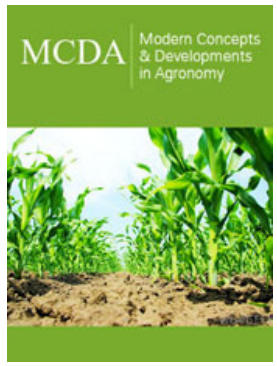

\section{Modern Concepts \& Developments in Agronomy}

\section{Benefits of Publishing with us}

- High-level peer review and editorial services

- Freely accessible online immediately upon publication

- Authors retain the copyright to their work

- Licensing it under a Creative Commons license

- Visibility through different online platforms 